\title{
Garden practices and their science
}

Book

Accepted Version

Preface

Dixon, G. (2019) Garden practices and their science.

Routledge, Oxford, pp. 1-416. ISBN 9781138485235 Available at https://centaur.reading.ac.uk/78443/

It is advisable to refer to the publisher's version if you intend to cite from the work. See Guidance on citing.

Publisher: Routledge

All outputs in CentAUR are protected by Intellectual Property Rights law, including copyright law. Copyright and IPR is retained by the creators or other copyright holders. Terms and conditions for use of this material are defined in the End User Agreement.

\section{www.reading.ac.uk/centaur}

\section{CentAUR}

Central Archive at the University of Reading

Reading's research outputs online 


\section{Preface}

Sharing the joys and stimulation of gardening is the aim of this book. Gaining greatest pleasures from working with and observing plants is increased by understanding some of the botanical processes happening before the gardener's eyes. Combining both gardening practices with seeing and feeling why and how plants deliver pleasure is the substance which makes horticulturists. Appreciating the live relationships between gardening practice and horticultural science defines the time when an enjoyable pastime moves into the realms of professionalism. In this context "professionalism" means a depth of understanding and knowledge which overlays practical skills. The gardener who knows why his or her skills make plants perform is truly an horticulturist.

Horticulturists understand the living entity that is a garden and may well take the appellation of "gardener" with great pride. Great horticulturists are often great gardeners, the floriferous landscape of Great Britain bequeathed by great horticulturists bears testament to that. This stretches from those who design and lay-out macro- and micro-landscapes to those capable of growing healthy and nutritious food.

People come into gardening and then become horticulturists along a wide diversity of pathways. For some, such as myself the introduction happened at a very young age. Others are enticed after having followed quite different life-styles and careers. Each can make their own individual contributions as gardeners and if they wish as horticulturists.

This Book describes some of the very basic gardening practices. These are given in detail with alongside them short pithy explanations of key botanical processes which happen during the gardening actions. Pleasures gained from growing plants, enjoying their beauty and productivity increase many-fold by deeper understanding of their life processes. Mentally and 
psychologically seeing the activities and interchanges happening inside the roots, leaves, stems, flowers and fruits is a joyful experience.

New entrant gardeners who may just have acquired "a plot" for the first time, early stage students, those with enquiring minds wishing for connections between practical and the underlying processes and perhaps more experienced practitioners who feel that they wish for an understanding of plant-life will find much of value in this book. It is written from the perspective of 70 plus years gardening experience and almost as long attempting a mental understanding of why things happen as they do.

One of my great mentors in the voyage into professional horticulture was Mrs Audrey Dixon (no relation), a gifted biologist who taught me at London University's Advanced and Scholarship Levels how to translate my interests in gardening into science and particularly botany and zoology. My parents Thomas and Nora Dixon sacrificed much in encouraging me to stay on at Grammar School enjoying that realisation and my wife, Kathy Dixon, has supported and sustained me in science and gardening for well over 50 years.

Sherborne, Dorset 